University of Nebraska - Lincoln

DigitalCommons@University of Nebraska - Lincoln

6-2007

\title{
Working on the Domestic Frontier: American Indian Domestic Servants in White Women's Households in the San Francisco Bay Area, 1920-1940
}

Margaret D. Jacobs

University of Nebraska - Lincoln, mjacobs3@unl.edu

Follow this and additional works at: https://digitalcommons.unl.edu/historyfacpub

Part of the History Commons

Jacobs, Margaret D., "Working on the Domestic Frontier: American Indian Domestic Servants in White Women's Households in the San Francisco Bay Area, 1920-1940" (2007). Faculty Publications, Department of History. 49.

https://digitalcommons.unl.edu/historyfacpub/49

This Article is brought to you for free and open access by the History, Department of at DigitalCommons@University of Nebraska - Lincoln. It has been accepted for inclusion in Faculty Publications, Department of History by an authorized administrator of DigitalCommons@University of Nebraska - Lincoln. 


\title{
Working on the Domestic Frontier
}

\author{
American Indian Domestic Servants in White Women's
}

Households in the San Francisco Bay Area, 1920-1940

MARGARET D. JACOBS

In 1934, "Opal," a young Pomo Indian woman who worked as a domestic servant in the San Francisco Bay Area, wrote in exasperation to the Bureau of Indian Affairs outing matron who had placed her in employment with Mrs. L. N. David of Berkeley: "Mrs.... David owes me ten dollars and she won't pay me for it. She accuses me of taking things which I didn't do. Do you remember when I left last July you told me to tell you if I didn't receive my pay to tell you. Well I didn't receive it and besides she accused the girl before me ... of the same thing. I think it's just a stunt to get out of paying me.... I wrote several letters to her, but finally gave it up as hopeless. She only paid me twelve a month." Opal also lamented that when Mrs. David "did let me go to Oakland for the dances she always wanted me to go up to the house to mow the land and kill fleas. The house was just infested with them. That is a terrible job by itself. That meant scrubbing all the ten rooms. She didn't give me a moment's rest, so I think it's terrible that she doesn't want to pay me. Will you please try and make her give me the $\$ 10$. . Opal added in a postscript, "I need the money terribly and I earned it, more than earned it so please make her pay me."

On the face of it, Opal's predicament did not differ significantly from that of other domestic servants in the United States in the early years of the twentieth century. Like Opal, most were female, impoverished, and racially classified as nonwhite, and they had few options for employment other than working as domestic servants. ${ }^{2}$ Many other domestic servants also suffered from the same kinds of indignities and toiled for the same low wages as Opal. Moreover, the relationship between employer and servant within the household has always been riven with inequalities that have divided women by class and often by race. ${ }^{3}$ This is not a new story.

However, household employment for Opal and other young Indian women did differ from that of other domestic servants in several key ways. First, Opal had not journeyed across the Atlantic or Pacific or trudged across a national 
border in search of wage labor; nor had she been freed from human bondage only to be enlisted into the lowest rungs of the American economy. Instead it was the colonization of her land and the subsequent federal Indian policy of assimilation that drove her and other young Indian women into domestic service.

Second, employment of young Indian women by white families became more than a private labor transaction between employer and employee; the Bureau of Indian Affairs (BIA) envisioned such employment as a central component of its assimilation policy. From 1880 up to the 1930s, as part of this policy, the BIA had removed thousands of Indian children to boarding schools. Many of the schools developed what came to be called "outing" programs, ostensibly to aid in the children's assimilation, which placed the children for part of each day and usually for entire summers with local families. Boys were usually set to work doing farm labor, while girls were to be employed in domestic service within the home. Even while in school, much of the education Indian children received revolved around training them for such menial positions, a process officials often characterized as making them "useful." " Enlisting white women employers in the project of "uplifting" and "civilizing" young Indian women made white women's households more than private homes or workplaces; they became domestic frontiers where colonial relationships continued to play themselves out. As in other colonies around the world, this intimate setting became a significant site for the reproduction and performance of colonial relationships. ${ }^{5}$

Third, the figure of the outing matron — an agent of the BIA—complicated the simple bilateral relationship between white woman employer and Indian servant. By employing outing matrons to oversee the employment of Indian girls and young women within urban households, the BIA attempted to maintain strict control over the young Indian women and to ensure that the white households in which they were employed provided the uplifting environment necessary to the servants' assimilation. Outing matrons in the San Francisco Bay Area compiled copious files from the 1920s through the 1940s on each young Indian woman that they placed in service, a record of documentation that suggests the intense surveillance and scrutiny under which the Indian servants lived and labored. ${ }^{6}$

Interestingly, however, the records also reveal the ways in which these Indian servants partially evaded the BIA's tight control over them. Young Indian women often refused to be wedged into their assigned roles of obliging servants and rejected attempts to "uplift" them. In hundreds of small acts on a daily basis, young Indian women like Opal asserted their own independence and agendas, chipping away at the façade of colonial hierarchy and order. Most of the young 
Indian women servants also cast aside or simply ignored the strict Victorianera sexual codes and gender norms that the BIA promoted in its boarding schools. Instead they appear to have maintained their own indigenous communities' norms regarding gender and sexuality while embracing the modern gender sensibilities of the city as well.

Ultimately, the state failed in its mission to assimilate young Indian women-that is, less euphemistically, to separate them from their indigenous communities and make them useful, as domestic servants, in the colonizers' economy. Ironically, many young Indian women used the state's agent-the outing matron-as a mediator in conflicts with their employers. Moreover most young Indian women apparently engaged in domestic service for just a short period of their lives-as part of a patchwork of economic strategies and perhaps as a youthful adventure-before returning to their reservations and rancherias. Nevertheless, if the state fell short of its goal to assimilate the young women, it still maintained some of its authority over the young women, particularly through asserting control over the children that many young Indian women bore while in service. Thus, as in the more visible conflicts over land and labor between colonizers and indigenous Californians, the domestic frontier also proved to be a site of ongoing tension, instability, and constant negotiation.

\section{COLONIZATION ON THE NORTHERN CALIFORNIA FRONTIER}

Most of the young Indian women who worked in the Bay Area between 1920 and 1940 came from a variety of Indian groups in northern California, Nevada, and Oregon, including the Pomos, Hoopas, Shastas, Monos, Paiutes, Klamaths, Washoes, and Western Shoshones. It would be impossible to cover the histories of each of these groups in an article, but a brief historical overview of the Pomos provides one example of the ways in which these groups had been colonized in the nineteenth century.

Just a few generations before Opal found herself killing fleas and scrubbing floors in the city for twelve dollars a month, the Pomos had claimed and lived upon a large swath of territory in northern California where the women gathered, leached, and pounded acorns to make their staple acorn mush and collected other edible bulbs, roots, seeds, herbs, nuts, and berries to complement the hunting and fishing that Pomo men usually carried out. Pomo women were (and still are) renowned for weaving the fibers of sedge root, willow rod, and redbud bark (and sometimes colorful feathers) into intricate anthill-and quail-patterned baskets ranging in size from the eraser head on a pencil to giant granaries in which to store acorns. In their roundhouse, Pomo women 


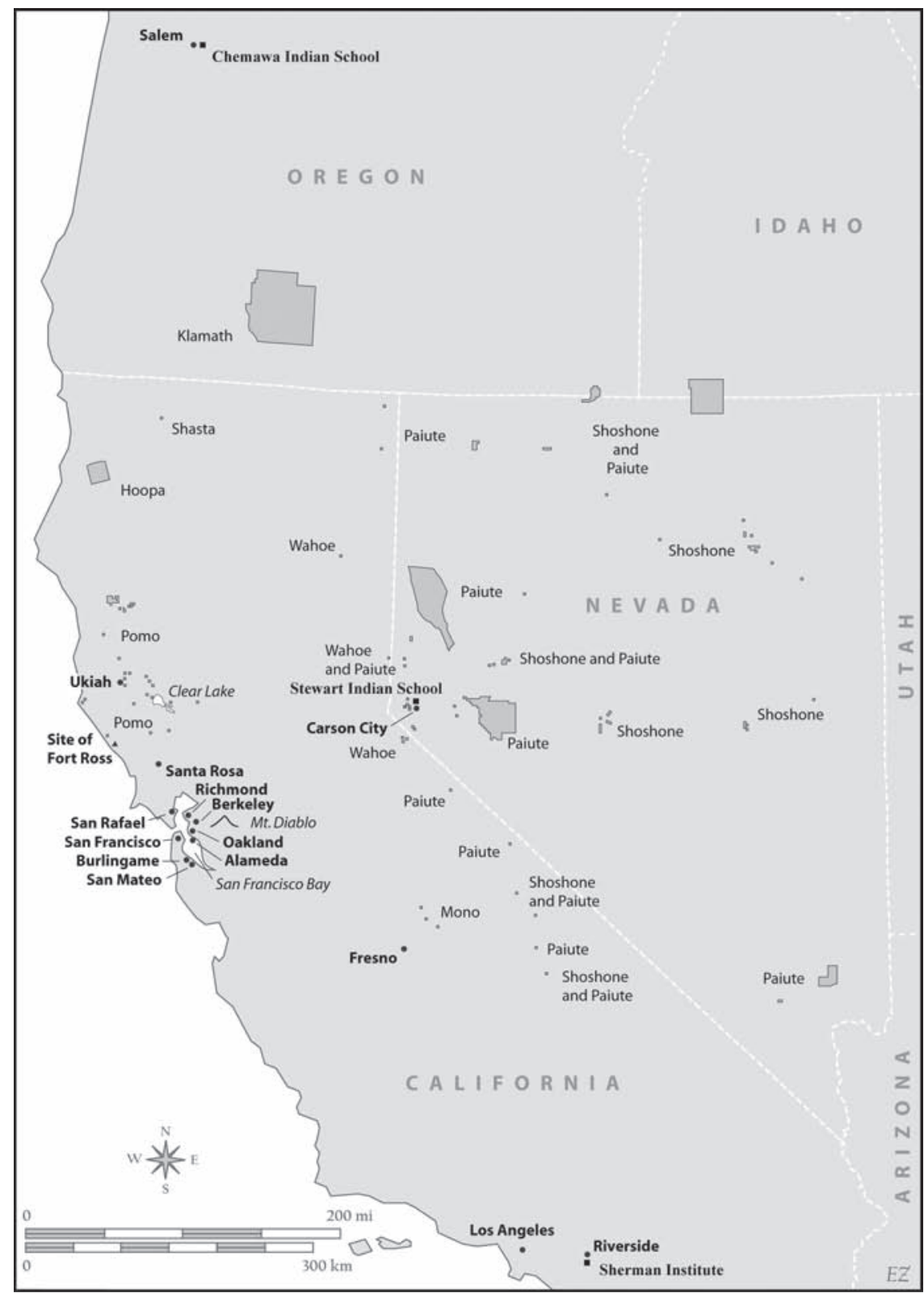

Figure 1: Map of California and neighboring states with locations of schools and Indian communities named in the text. Drawn by Ezra Zeitler. 
danced and worshipped. Some became highly esteemed healers, and a few Pomo women took leading roles as Dreamers in the revivalistic Bole Maru religious movement that began in the winter of $1871-72 .^{7}$

By the 1870s, four waves of colonization-from the Russians, Spanish, Mexicans, and Americans-had already buffeted the Pomos. In 1812, the Russians had established a trading colony at Fort Ross; five years later, Spanish friars erected a mission at San Rafael. ${ }^{8}$ Both the Russians and the Spanish conscripted some bands of the Pomos into forced labor; the Spanish also sought to convert some Pomo groups to Christianity. Europeans had also introduced deadly diseases among the Pomos, who suffered a drastic decline in population, especially as a result of the great pandemic of the 1830s. When Mexico obtained its independence from Spain in 1821 and secularized the missions, it then subjected the Pomos to a new round of slave raiding and trading. By 1842 , the Russians had abandoned their fort, but a new crop of colonizers from the United States had begun squatting on land in California. After the Americans conquered the territory from Mexico in 1848, the Pomos suffered from a new and precipitous population decline, brought on by increased disease and starvation. In 1850, the new California state legislature enacted "An Act for the Government and Protection of Indians," which despite its benevolent name, amounted to allowing Indian children to be kidnapped and virtually enslaved. ${ }^{9}$ Outright massacres of the Pomos- the most famous at Clear Lake in 1851-also decimated and demoralized the group. The Pomos also lost 99 percent of their homelands to the invaders. Other Indians in the region endured a similar fate. ${ }^{10}$

In the 1850s, U.S. government troops rounded up the remaining Pomos and marched them to two newly established reservations, the Mendocino and Round Valley reservations. With inadequate rations, however, many reservation residents became ill and malnourished. Many Pomos fled the reservations in search of better conditions. By the late 1870s, many groups of Pomos pooled their money to purchase land to create their own small rancherias. When most of these Pomos later lost this land to unpaid taxes or defaulted mortgages, the government in the early 1900 set up other small rancherias to accommodate the dislocated Pomos. ${ }^{11}$

Without their original tracts of land, the Pomos found it more difficult to maintain their earlier subsistence activities. Pomo men gave up their traditional hunting to shear sheep and work in the new logging industry. Beginning in the late 1860 s, Pomo women became hop pickers and servants in the new invaders' homes. ${ }^{12}$ On the other hand, Pomo women managed to continue some of their gathering and foraging activities in the late nineteenth century; as late as 1900, the Pomos still relied primarily on their traditional diet of clover, bulbs, 
seeds, nuts, and acorns that Pomo women had harvested for centuries. By the late 1920s, however, the Pomos had become almost wholly dependent on wage labor and new American foodstuffs. ${ }^{13}$ Other indigenous peoples in northern California, Nevada, and Oregon at the turn of the twentieth century also lost their ability to subsist from their land and became increasingly dependent on government assistance, wage labor, or both.

A century of colonization had also undermined Indian social patterns and gender systems in the region. Among the Pomos, according to Elizabeth Colson, who conducted anthropological research among them in the late 1930s, gender relations had been closely regulated before the incursion of American soldiers and settlers, many of whom sexually assaulted Pomo women or took them for their mistresses. "The old marriage system with its permanent binding of families together to ensure the welfare of the children had already suffered somewhat from the disruption of the groups caused by slave raids, massacres, and forced removals," Colson writes. When the Pomos settled on reservations and rancherias, according to Colson, "following the example of the Whites whom they best knew, the Pomo discarded permanent unions." 14 When Juliet Lombard studied the Pomos at the same time as Colson, she found that "a young person almost always has a series of ... affairs before he or she finally contracts a lasting marriage." Moreover, the Pomos rarely legalized their marriages; as Lombard explains, "[W] hen an Indian man and woman live together for a long period of time, they are considered married." 15

\section{ASSIMILATION ON THE DOMESTIC FRONTIER}

By the late nineteenth century, American colonizers in the region had accomplished one of their imperial aims: they had wrested much of the land from its indigenous inhabitants. Yet, as in the rest of the American West, BIA officials and reformers complained that a so-called Indian problem remained. Although their land base and traditional lifeways had been severely compromised, Indian people still tenaciously held some land, where they could maintain their distinctive identities, innovate new rituals and ceremonies, and evolve new social practices. At the same time, because Indian peoples had lost much of their land and their traditional means of subsistence, they had grown partially dependent on the government for food assistance. In short, the colonization of Indian peoples was not complete.

In the late nineteenth century, to solve this "Indian problem," the U.S. government masterminded a new policy-assimilation-which advocates characterized as a benevolent enterprise to help Indian people adjust to "civilization." In reality, assimilation functioned as an effort to consolidate coloni- 
zation through attempts, as one white women's reform organization put it, to carry out "the vastly needed work within Indian hearts, minds and souls." 16 On a more pragmatic level, the BIA also hoped to end its trust obligationsincluding the provision of rations and annuities - to Indian peoples. The BIA set about implementing its new policy by allotting communally held land among several tribes to individual Indians, enacting a Religious Crimes Code in an effort to eliminate many Indian religious ceremonies and practices, and removing thousands of Indian children to boarding schools far from the supposedly harmful influences of their home communities.

Initially, Indian children obtained a varied education at some of these schools, but by the early twentieth century, the curriculum in the Indian schools centered on training boys for menial occupations and girls for domestic service. ${ }^{17}$ In 1901, for example, Estelle Reel, the Superintendent of Indian Education from 1898 to 1910, declared that "the importance of holding the work strictly within practical lines can not be too strongly impressed upon the instructor." 18 Another administrator seemed to view the boarding schools as factories that were turning raw material-Indian children-into useful goods. "We must labor with a more definite aim in these schools to fashion this human material into something for which there is a demand," he wrote. "Until we have done this we can not hope for great success in finding locations for our products." 19

Outing the children to work for and live with white families became yet another part of the assimilation program. White policymakers and authorities characterized the outing of Indian girls for domestic service not just as a job but as a necessary part of their curriculum in "uplifting" Indians from savagery to civilization. As Estelle Reel put it, the outing system "places the student under the influence of the daily life of a good home, where his inherited weaknesses and tendencies are overcome by the civilized habits which he forms-habits of order, of personal cleanliness and neatness, and of industry and thrift, which displace the old habits of aimless living, unambition, and shiftlessness." ${ }^{20}$ Thus, authorities ennobled domestic service and invested white women employers with an important role in "civilizing" Indian girls and young women.

At the same time, a growing demand for domestic servants in California and other parts of the American West provided a ready market for the newly trained Indian girls. San Francisco and its environs had grown enormously since the U.S. had seized the territory from Mexico in 1848. At that time, San Francisco had only about one thousand inhabitants, but partly because of the Gold Rush and the completion of the transcontinental railroad, the city's population had increased in size to more than 340,000 by the early 1900 , making 
it the ninth-largest city in the United States. Until 1920, it was the largest city west of the Mississippi River. ${ }^{21}$ New middle- and upper-class women residents of the city would have sought out domestic servants, but found few available in the 1920 s and ' 30 . African American women, who worked extensively as domestic servants in the East, did not make up a sizable pool of laborers in the San Francisco area or in other Western locations until World War II, and at that point they eschewed domestic service for better-paying jobs in ship-building and other defense industries. ${ }^{22}$ Mexican women immigrants and Chinese and Japanese immigrant men had served as domestic servants from the late nineteenth century up through the 1920s. Yet during the era in question, immigration from Asia had been curtailed by the 1882 Chinese Exclusion Act and the 1924 Immigration Act. Moreover, at least 500,000 Mexicans were deported or repatriated during the Depression. Therefore, there would have been a scarcity of domestic servants in the San Francisco Bay Area. ${ }^{23}$ The superintendent of Carson Indian School noted in 1930, in fact, that in the Bay Area, there were "more applications for girls to assist in families than there are girls." 24

Although large numbers of Indian women undoubtedly worked as domestic servants in the early twentieth century, especially in the American West, few historians have studied or written about the topic. ${ }^{25}$ Scholars have been peculiarly silent about this topic perhaps because of longstanding interest in Indians primarily in their traditional, premodern settings. Works on Indian women have tended to focus on questions of the extent of their status in their traditional societies and how their status changed over time with European contact. ${ }^{26}$ As more scholars, however, turn their attention to what Philip Deloria calls "Indians in unexpected places," American Indian women's experience as domestic servants and their encounters with modernity will undoubtedly invite additional research. ${ }^{27}$

THE DOMESTIC FRONTIER AS A CONTACT ZONE

As BIA agents placed Indian girls and women in white women's households, the "frontier" - once thought of as the hinterlands on the edge of civilization and more recently conceived by scholars as a contact zone between indigenous people and their colonizers-moved into new intimate spaces, often within urban areas. ${ }^{28}$ Geographer Janet Henshall Momsen explains, for example, "Domestic space can be seen as a contact zone within which negotiations over 'otherness' and identity, based on race, class, religion, age, education, sophistication and citizenship are constantly underway." ${ }^{29}$

This new domestic frontier, in fact, grew out of colonial conflicts on the geopolitical frontier. Evelyn Nakano Glenn has pointed out that domestic ser- 
vice is integrally related to colonialism. She observes that "labor migrants are drawn from 'backward' areas whose economies have been disrupted and subsequent development distorted by western colonial incursions. The distortion of the economy leaves large segments of the population with their usual means of livelihood interrupted. Many are thus free to be torn from their roots and recruited to fill labor needs in the advanced regions, often the source of the original incursion." ${ }^{30}$ More recently, the globalization of the economy has created inequities that lead to the migration of impoverished women from a rural to an urban setting or across international boundaries to take up employment in privileged homes within rich countries, a practice that Hondagneu-Sotelo calls the "New World Domestic Order." ${ }^{11}$ This global colonial phenomenon was already operating in relation to Indian peoples within the boundaries of the United States during the first decades of the twentieth century.

The domestic frontier not only functioned as a side effect of "larger" colonial conflicts but also served to reproduce and re-enact colonial relations on a daily basis. American Indian women's domestic service in white women's homes thus becomes a key arena in which to study what Ann Laura Stoler calls the "intimacies of empire" or "the quotidian shaping of racialized colonial worlds and their disparate sites of production." ${ }^{32}$

AMERICAN INDIAN DOMESTIC SERVANTS IN THE

SAN FRANCISCO BAY AREA

In the Bay Area, no Indian boarding schools existed within a convenient distance for Indian girls to be outed on a daily basis, but in 1918, the BIA hired Bonnie Royce, wife of the superintendent of the Stewart Indian School in Carson City, Nevada (often referred to as the Carson Indian School), to place young Indian women from the surrounding area in domestic service. The Commissioner of Indian Affairs stipulated that Royce "give special attention to procuring [employment in] homes for Indian girls after they have left school or for any other Indian women of Nevada and Northern California . . . , in order that they may be protected from the degrading moral conditions which are found in the small mining towns of Nevada and the country adjacent thereto." He also gave Royce strict instructions: "The field [outing] matron should ascertain the character and reputation of the parties wishing Indian help and make regular visits to the homes where such employment is given so that no mistake may be made in placing these girls in homes only where helpful influences are radicated [radiated]." ${ }^{33}$

Royce first established the placement office in Berkeley; it later moved to Oakland, and later still, across the bay to San Francisco. Royce served as outing 


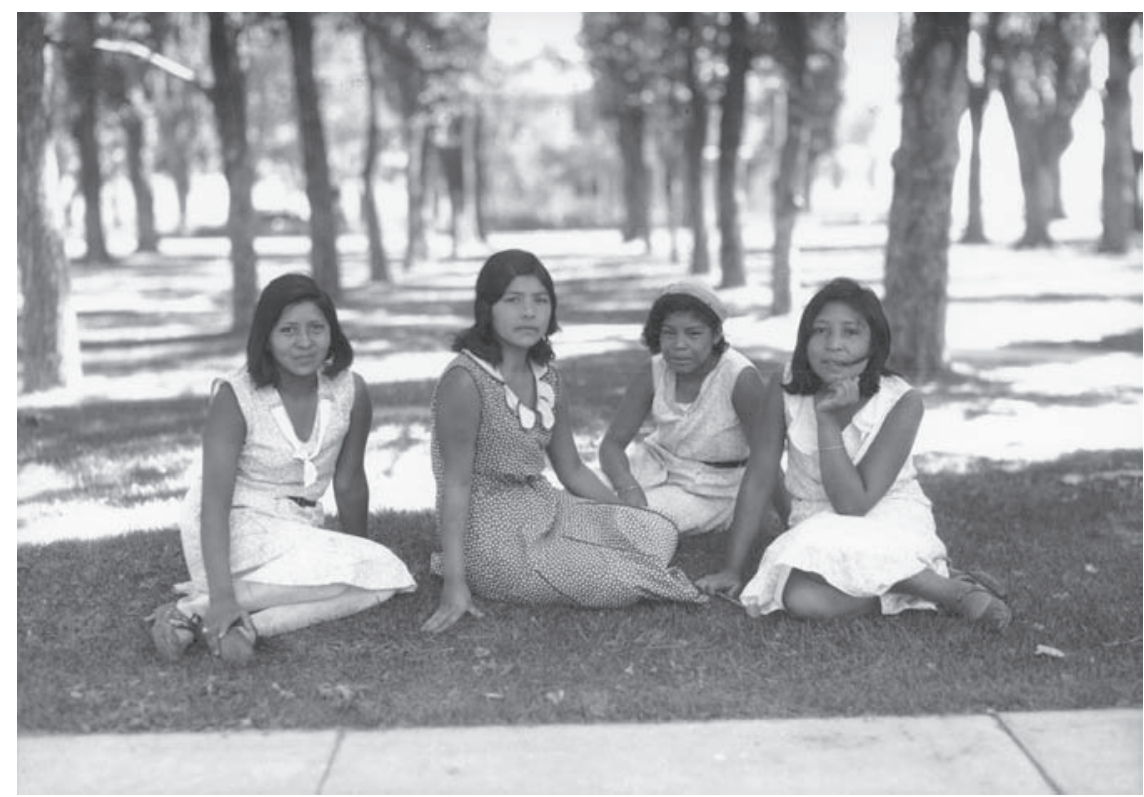

Figure 2: Photograph No. 11, "Girls sitting on grass" (photograph of children and grounds of Carson/Stewart Idian School, ca. 1935); Decimal Subject Files, 1925-1950; Records of the Carson Indian Agency, Records of the Bureau of Indian Affairs, Records Group 75, National Archives and Records Adminsitration-Pacific (San Francisco).

matron until the early 1930s; she convinced the BIA to hire Jeannette Traxler as her assistant in 1929, and Traxler appears to have taken over from Royce sometime in the early 1930s. In 1934, the BIA hired a new matron, Mildred Van Every, who worked in the post until $1946 .{ }^{34}$ Although Royce began her work in the 1910s, the outing office did not begin to keep detailed files on the young women until 1925. This article is based on an examination of ninety-seven of the most detailed files.

Given the origins of the program, many of the young Indian women who came to work as domestic servants in the Bay Area had attended the Carson Indian School. During the summer of 1929, for example, of forty-one Indian girls outed for the summer, twenty-seven were from the Carson school. Of the eighty young Indian women permanently outed in the Bay Area in 1929, twenty-eight were from the Carson school. Others had been enrolled at Chemawa Boarding School in Salem, Oregon, or Sherman Institute in southern California or attended unidentified public schools (an increasing trend among Indian children in the 1920 s and ' 30 ).$^{35}$ Juliette Lombard notes that two-thirds of the Pomo women from the Ukiah valley north of San Francisco 
who took domestic jobs in the Bay Area had attended Sherman Institute. ${ }^{36}$ She also reveals that "by 1941, more than a third of Ukiah Valley Indian women [in northern California] between the ages of fifteen and thirty had worked for some time in the Bay Area." ${ }^{37}$

Young Indian women learned of employment opportunities through the placement service in one of three ways - through referrals from boarding school or reservation officials, through word of mouth among the young Indian women themselves, or through recruitment efforts by the matrons. Matron Van Every visited Sherman Institute every summer and traveled frequently around northern California to recruit young Indian women. The BIA records also indicate that the matrons often corresponded with officials on the reservations or in the boarding schools the girls had attended..$^{38}$ Other young Indian women found domestic employment in the Bay Area through a competing private placement service. Royce complained to Superintendent Frederic Snyder of the Carson School in 1930, in fact, that "For the past two years a Mrs. H.C. Roberts, whose husband has charge of a fish cannery at Requa, California, has been responsible for bringing a number of Indian girls to this [East Bay] District to work. When she started this work it was with my knowledge and with the understanding that she would co-operate with this Center. However, as time advanced the girls came without my knowledge and were placed in homes by Mrs. Roberts, who I think, uses poor judgment in the placing of the girls, and ignores our rules and regulations." ${ }^{39}$

In the trilateral relationship that developed along the domestic frontier between the young Indian women, their white women employers, and the BIA outing matron, each group had its own interest and priorities. ${ }^{40}$ The records compiled by the outing matrons actually tell us little about the motivations of white women employers and the outing matrons themselves, but understanding the larger context of middle-class women's work and domestic life in the early twentieth century may shed light on why white women became involved in this enterprise. The outing matrons seem to have been motivated in part to take up this line of work through the influence of the Progressive maternalist women's movements. At least one outing matron emerged from a women's reform organization with maternalist orientations. Van Every had close ties to the Young Women's Christian Association (YWCA) and served as Industrial Secretary for the Oakland branch in the 1930s. She also appears on their Indian Girl's Work Committee for $1942 .{ }^{41}$ Van Every also relied on maternalist networks in her work with young Indian women and girls. For example, in 1934 Edith Murphey, the chair of the Indian Welfare Committee of the California Federation of Women's Clubs, wrote to Van Every that she wanted to place two Indian sisters in domestic employment in the Oakland area. ${ }^{42}$ Working 
through such women's organizations and clubs for social reform, maternalists often justified women's presence in public reform as a natural extension of their experience or socialization as mothers, upheld a maternal and domestic role as most fitting for other women, and sought to mother other seemingly disadvantaged women. ${ }^{43}$

The outing matrons may also have been motivated to take up these new positions through a desire for professional advancement. In the early twentieth century, many other maternalist reformers maneuvered themselves into unprecedented positions of professional authority through government agencies, including the newly established Children's Bureau and Women's Bureau. ${ }^{44}$ The large numbers of white women who worked as teachers and matrons (and less commonly as principals and superintendents) for the BIA represent another way in which white women institutionalized maternalist sensibilities within federal agencies in the late nineteenth and early twentieth centuries. In his study of Indian boarding schools, David Wallace Adams found that "the average teacher appears to have been a single woman in her late twenties." Indeed, Cathleen Cahill discovered that the proportion of women employees in the BIA's School Service "held steady between fifty-five and sixty-two percent" from 1890 well into the twentieth century. ${ }^{45}$

The BIA readily believed that white women's maternalism could be put to the service of its assimilating mission. When he appointed Royce as outing matron, Commissioner of Indian Affairs Sells defined Mrs. Royce's mission as a maternal one. "I feel that there is a great work to be done in Nevada for these Indian women," Sells concluded, "and from the experience that Mrs. Royce has had in Indian work believe that she will be able to give the girls the motherly advice and encouragement which will prove an uplift to those placed in her care." ${ }^{\prime 6}$ Thus, by building on their associations with domesticity and motherhood, white middle-class women created a new avenue toward professionalism and self-support.

The outing matron's records reveal even less specific information about the white women employers and their motivations, but it might seem obvious why such women sought out domestic servants-simply to help with household work. Yet as many scholars of domestic service have pointed out, acquiring a domestic servant also carried with it a badge of class and racial status that made it possible for women employers - most of whom were white- to meet middle-class standards of cleanliness while escaping the drudgery that such standards required. ${ }^{47}$ As Pierrette Hondagneu-Sotelo explains it,

Even among wealthy white women born and raised in the United States in the late twentieth century, few escape the fetters of unpaid social reproductive labor. As many observers have noted, their reliance on house- 
cleaners and nannies allows well-to-do women to act, in effect, as contractors. By subcontracting to private domestic workers, these women purchase release from their gender subordination in the home, effectively transferring their domestic responsibilities to other women who are distinct and subordinate by race and class, and now also made subordinate through language, nationality, and citizenship status. ${ }^{48}$

Certainly, on a recently colonized frontier with a shortage of domestic servants, white middle-class women in the Bay Area would have been anxious to assert their status through employing a domestic servant. Some white women employers - who were also undoubtedly influenced by the maternalist movements of their time-may also have been drawn to the ennobled mission of participating in the "civilization" of young Indian women.

Young Indian women, of course, had their own distinctive reasons for participating in domestic service. Some Indian girls, who were outed directly from one of the boarding schools for the summer, had little say in the matter. Other young women, who had graduated from or simply left the boarding schools, may have turned to domestic service because they could find little other employment. By the early twentieth century, the notion that Indian women were suited for little else but domestic service predominated. Juliette Lombard, carrying out research in the 1940s among the Pomos in the Ukiah Valley, found that even though many of the young women she encountered had been trained as beauticians, nurses, or in clerical work, none could find work in those occupations. ${ }^{49}$

In contrast to the dearth of documentation regarding white women's involvement in the enterprise, the BIA records reveal a host of other reasons why young Indian women sought domestic service positions. When the Depression hit, Indian women's options narrowed further as their need to earn money became even greater. "Wynona," a Mono Indian, wrote in search of a position because "I am quiet $[s i c]$ interested, as we certainly feel the depression. I will quit school in a minute to secure a job for fifty dollars per month as a cook." ${ }^{50}$ Some supported family members. "Daisy," a Shasta Indian who had three children, wrote to one of the matrons, "[I] have left my husband, he is worthless and cruel.... I tried to stay with him for the children's sake but he is just impossible. I am at home with mother now.... Must get some work to do soon as my three children and I are without shoes or clothes." ${ }^{51}$ During these hard times, many Indian women might have viewed domestic service as one part of an overall economic strategy. Many young Pomo women, for example, often worked picking hops in the summers and serving in white women's households in the Bay Area for the remainder of the year. ${ }^{52}$ 
While the BIA records do not reveal the larger familial and communal context for these young women's work, other scholars' recent studies on American Indian labor in the twentieth century suggest that Indian workers conceived of wage work more as a means to contribute to their families' household economies than as a means to gain individual advancement. Moreover, Indian wage earners often modeled their employment on the seasonal round of subsistence economic activities in which their communities had once engaged. As Colleen O'Neill puts it in relation to Navajo wage work, "The Navajos negotiated the encroaching world market selectively, participating in it when it suited their purposes, but refusing to allow capitalist cultural and economic logic to significantly undermine the basic premises upon which they had shaped these new economic strategies." ${ }^{53}$

Some of the young women experienced extreme prejudice and lack of opportunity in their home communities. In the Ukiah Valley, where many of the Pomo women came from, most white families and white-owned businesses refused to hire Indian women. Local Indians there also faced segregation in housing, restaurants, movie theaters, and even beauty parlors. One young Pomo woman from the area declared, "I don't want to live on any rancheria! I want to go away some place and study and study and be left alone." ${ }^{4}$

As this writer's comment makes clear, the young women had other reasons for moving to the city for domestic work beyond a simple lack of money. Some simply wanted adventure and to experience something new. "Irene," from Salt Lake City, "was particularly interested in seeing the Golden Gate International Exposition, and to find out whether she could make Indian articles at the Exhibit." ${ }^{55}$ Indian women also seemed to regard domestic employment as a route to some form of independence, sometimes from the paternalism, control, and surveillance they faced within boarding schools or on their reservations, but also on occasion from the abusive situations within their own families. "Elsie," a Washoe, told Van Every that "she did not intend returning to the man with whom she had been living near Fresno but would rather make her own living." ${ }^{56}$ Some of the girls envisioned domestic jobs as the means eventually to attain a college education or professional training. "Clara" wanted to work for a while in order to save money to go to Willamette University. ${ }^{57}$ "Edith," a Winnebago who had studied nursing for two years at Haskell and then worked for two years as a nurse (and had a "fine contralto voice"), came to the Bay Area to study voice while working as a domestic. ${ }^{58}$

Many young Indian women also sought out domestic jobs in part for the social opportunities they afforded. "Helen," according to her employer, "talked on the telephone a good deal each day, and seemed to have many friends at the University." ${ }^{59}$ The YWCA sponsored the Four Winds Club in 
Oakland for the young Indian women and men in the Bay Area, where they met every Thursday night and held chaperoned dances once a month. ${ }^{60}$ "May" wrote one of her friends, "Amelia," "Well, my pal, they had a party Thursday night as usual. I was there, I saw all my pals from Richmond, all of them boys ... and all the girls." ${ }^{\prime \prime 1}$ Others relished dancing and drinking in the city out from under the watchful eyes of the matron at the YWCA or their employers. Mrs. Scott let "Caroline," a Western Shoshone girl, go "because she was staying out late-drinking." ${ }^{62}$ Notably, these young women largely sought out the company of other Indian women - and a few Indian men-in the Bay Area. Their efforts to connect with other urban Indians, whether from their own tribe or not, laid the foundation for the urban pan-Indianism that would flourish after World War II. ${ }^{63}$

So important was this social life to the young Indian women that many of them refused or resigned from particular jobs if they cramped their social opportunities. For example, "Fern" and Amelia wrote to Royce in 1929 about how unhappy they were working at the Mt. Diablo Country Club (inland from the Bay Area). They pleaded with her, "We can't stand it here any longer. Too hot, lonesome, and everything. We would like to work some place else, where we can see the girls on our day off. It feels terrible not to see them, and that were [sic] way off. ... Can you please get us a better place. We can't stand the heat and we can't cook to suit them.... We would rather work there [in] the city than out here. Please get us a place there." ${ }^{64}$

Although some of the Indian women may have taken the jobs for adventure, independence, or social opportunities, they spent most of their time carrying out the duties assigned to them by their white mistresses and expected of them by the matrons. As May put it in a letter to her friend Amelia, "I guess you know that Royce lady make [sic] you work. I've been working like hell every [sic] since I got here." ${ }^{65}$ Indian girls and women who worked as domestics were charged with basic cleaning and additional responsibilities such as caring for children, cooking, ironing, serving the table, and answering the door bell and telephone. Wages varied considerably for young Indian women. In the 1920s, "Jane," a Washoe, made \$50 to \$65 a month, whereas in the Depression of the 1930s, "Susan," a Klamath, earned just \$20 a month while Opal, at one low point, only took in $\$ 12$ one month. ${ }^{66}$

In their relationships with their employers, the young Indian workers experienced many of the same problems and conflicts that other women did in other domestic service arrangements. The agendas of employers often clashed with the priorities of the young Indian servants, and perennial conflicts that seem inherent to domestic service-over wages, hours, types of work, and leisureensued. White women employers wanted obedient and dedicated servants 
who would work long hours for low wages. After her servant "Hannah" left because "she would rather work in Oakland where she knew someone and where it was a larger place," Dorris Taft of San Mateo wrote to matron Traxler to request a new servant, but one who would work for fifteen dollars a month. Taft informed Traxler that in San Mateo they did not pay twenty-five dollars and up and "I would like awfully to get a good girl, but one who will stay, this changing and training is a very hard thing both on the girl and on me." ${ }^{67}$

White women employers also wanted to control how their Indian servantsmost of whom boarded with their employers—spent their leisure time. Mrs. Parlier of Berkeley was annoyed when her servant "Sylvia" went with her girlfriends to San Francisco in a taxicab. She was "indignant that people who did household employment should spend their [money] in that way." ${ }^{18}$ Van Every wrote that Susan "does not accept criticism" and that she "resigned [as] Mrs. Wright's employee because she asked her not to remain out past midnight." 69 Conflicts over leisure had long been a source of friction between white women and African American women servants as well. Many African American women solved this problem by saving up enough money so they could live separately from their employers. ${ }^{70}$ Because Indian women were expected to live with white families as part of their "civilization" program, this option was not available to young Indian women servants.

As was common in other domestic service arrangements, white women also sought to command deference and strict obedience from their employees and were upset when many young Indian women seemed unwilling to conform to their demands. On the outing form of "Iris," for example, the matron wrote, "Good girl—slow. Very impudent to Mrs. Lester. Mrs. Maurice says not clean or good worker." "Louisa" "did not make good at first place. Stayed out nights left Mrs. Wilson's. Mrs. Moore let her go because out all night and saucy." "71 Grace Cresap wrote to Royce that her two Indian servants "have been sullen. They do their work, but not in a happy manner; neither Mr. Cresap nor I can stand having ill tempered people about us." 72 As these cases illustrate, white women employers were disappointed in young Indian women who were "impudent," "saucy," and "sullen" and refused to play the role of obedient, humble, and grateful servant in need of guidance, protection, and "civilization."

For their part, like other domestic servants elsewhere, the young Indian women merely sought employment with reasonable hours and decent wages with full control over their leisure time. American Indian girls and women routinely objected to the low salaries white women tried to pay them. Many, like Opal, found it difficult to get their employers to pay them their full wages in a timely manner. "Anne," an experienced young woman from the Colville Reservation in her early 30 and married to a Sac and Fox man who was in 
the Navy, wrote to Van Every about her employer, Miss Ellis. "I found her very pleasant, and we talked about the work so we are going to try it. One thing I couldn't get her to promise to pay me \$40.0o[.] And in the future if she still don't see to pay me my price; I am only going to promise you that if she don't I don't want to stay with her for only $\$ 35.00$ That is after a week's trial." 73

The type of work the young women were asked to do also grated on them. "Emmeline" lost her "place at Johnstone's because of late hours, swearing and complaining of the wash." ${ }^{\prime 4}$ In particular, many young women grew weary of having to take care of white women's children. Hannah wrote to Royce, "I am on my way to my sister's.... I tried for 2 months to grin and take what came my way-and tell you people I was happy — up till now. I had no privacy whatever- the kids slept in my bed—used my things—sassed me back." On top of this, according to Hannah, "She [her employer] expected me to take care of the kids and do house work at the same time-which I just could not do. They [the kids] wouldn't mind-then she thought I was in the wrong." 75

Indian servants also chafed at the restrictions their employers placed on their social lives. Hannah complained to Royce, "On my days off I was let off so late, that it really wasn't worth going out. When I went over to Oakland ... I [had] no time to get ready, and then had to make up for it with a lot of work." Hannah also disliked the sense of being constantly monitored and judged during her leisure time. "Last year I was only at a show and it was told to Mr and Mrs Wright [her employers] that I was 'running wild' down at Oakland," Hannah confided to Royce. ${ }^{76}$ "Myra's" intercepted letter to her boyfriend also reveals how much the young Indian women resisted their white women employers' control of their leisure. After staying out late with her "dearie," Myra wrote to him,

I am writing to tell you what a time I had last night. ... I was locked out [of her employer's home] so I couldn't come in, I sure wished I stayed with you then. I am here at the YWCA now writing you these few lines. Well, Honey, so I might not get to see you Sunday.... Maybe I have to stay Home all-day. It certainly will be tough. If I can't see you. ... .

Well, Mrs. J. call Mrs. Royce up this morning, and told her I was locked out and she told Go right Back to Mrs. Johnson, But I haven't started yet. Hell with Johnsons. They make me sick all over. I might be going Home to Ukiah, on the next Train that pulls out for all I know. ${ }^{77}$

It is clear when looking at cases like those of Hannah and Myra that in a number of significant ways Indian women's experience of domestic service differed significantly from that of other young women who took on the same work. First, another tension complicated the unequal class and race dynamics 
already inherent in servant-employer relationships in the United States. In this case, in trying to carry out the role envisioned for them by the BIA-as maternalist civilizers of Indian women-white women employers often claimed to be not only employers but uplifters who needed to protect and shape the morals of the young Indian women in their hire and care. Mrs. Harrington of Burlingame, south of San Francisco, for example, asked Royce, "Let me know-how late may she [her servant] stay out at night? She has a friend in the city-an Indian girl and last Sunday they went to a dance. I feel F. is a fine girl and one to be trusted, but I simply wanted to know whether I am responsible for her hour." ${ }^{78}$ Like Myra, most of the young servants seem to have resisted their employers as maternalistic and uplifting figures. Wynona, for example, according to Royce was "going with associates whose influence we think is bad; she ignores all our advice and that of her employer." ${ }^{\text {"79 }}$

Second, the presence of the outing matron further muddled the domestic service relationship between white woman employer and Indian employee. BIA records reveal that the matrons scrutinized the work lives and leisure hours of the young Indian women. The matron kept files that rated the girls on many of their household tasks. For Elsie, the matron noted:

$\begin{array}{ll}\text { Care of Children } & \text { Poor } \\ \text { Cooking } & \text { Assist, no experience } \\ \text { Ironing } & \text { Yes } \\ \text { Answering Door Bell } & \text { Yes } \\ \text { Answering Telephone } & \text { Yes } \\ \text { Serving the table } & \text { No training }\end{array}$

The matrons often rated the girls not just on their work skills but also on their behavior in the workplace and their morality. Van Every wrote of Ruth that she was "Moody." Under the Morals category, Van Every wrote simply, if inexplicably, "No Standard." ${ }^{81}$ Royce complained of one young woman: "I have had considerable trouble with [Rebecca]. She left her place of employment and claims she went to Santa Rosa but I think she was hiding in Oakland. If so, of course there was a boy in the case. I have tried so hard to keep tabs on [Rebecca] for I really like her and hoped to be able to make something of her." 82 (Royce's comment conveys the strong current of maternalism-a desire to make something of Rebecca- that ran through her work as outing matron.) While other domestic servants certainly had to put up with many of the same conflicts with their employers, only Indian domestic servants were subjected to this level of scrutiny and the presence of a third party, a representative of the federal government, no less.

At times, the young Indian women servants could use the presence of this 
third party to their advantage; they sometimes called upon the mediating position of the outing matron to gain greater leverage with their white women employers. When Opal "was offered a job with Mrs. Wacs[,] [Van Every] urged her not to take the hob [sic] at the low wages offered." ${ }^{83}$ And when Opal's former employer, Mrs. Whittaker, refused to pay her the \$3.82 she was owed, Van Every "urged her to write Mrs. Whittaker about the money." A few days later, "Mrs. Whittaker called [Van Every] on the telephone and later came into the office protesting that she would not pay [Opal]. [Van Every] maintained that the amount was due to [Opal]." Just two days later, "Mrs. Whittaker left a check for [Opal]." " The Oakland YWCA (with which Van Every was affiliated) also organized its Amicitia and Four Winds Clubs to assist "in the introduction of the Bill limiting the hours of employment in this occupation [domestic service] to fifty-four." These clubs "helped raise a lobby fund and some went to Sacramento at the time of the vote on the Bill, which was defeated." ${ }^{\prime 5}$ Thus, the matrons, on occasion, could become allies of and mediators for the young Indian women rather than (or in addition to) government agents bent on monitoring and controlling the servants.

As Rebecca's case suggests, however, more often than not, many young Indian women seem to have rebelled against the interference, control, and monitoring of the matrons as much as against the maternalism of their employers. Royce claims she tried to help "Sharon" (Western Shoshone) and another unwed Indian mother find a place for their babies, but Sharon went against her advice and also behaved impudently to her employers. "[Sharon] continued to be disagreeable and gossiped with Mrs. [H.], who was boarding the baby, about her employer and also about her mistreatment from me. [Sharon] evidently got sympathy from Mrs. [H.], as Mrs. [H.] advised her that the Government had no control over them and that they could go on their own if they wished; I understand she consulted a lawyer concerning this. This created an independent spirit in the girls and they became absolutely unmanageable." ${ }^{\prime 8}$

The young Indian women particularly resented the control that authorities often still had over their monies, another important difference in the experience of outed Indian girls and women as compared to other domestic servants. "[Sharon] called me on [the] phone last week and demanded the funds I had in my office," Royce wrote to Emmett E. McNeilly, Superintendent of the Western Shoshone Agency. "When I told her I had transferred same to you she was very abusive and talked as no other girl had ever done. All this is very humiliating; considering the patience I have had with her and all the trouble and care she has caused." Royce lamented, "I have done all in my power to advance these girl's $[s i c]$ welfare and have to acknowledge defeat for the first time, as [Sharon] is the first girl to positively refuse my supervision." 87 "Ruby" 
had also written to Superintendent Snyder of Carson Indian School to withdraw all of her wages, but Snyder told her that her request had arrived too late and that "we think it is a better way to handle the money than to have the people pay it direct to the girls, we then have a record of what money the girls have earned during vacation." ${ }^{88}$

Other young Indian women butted up against the limited career options open to them and challenged the low expectations of their employers, matrons, and reservation and school officials. "Margaret" shared her frustration with John Collier, the newly appointed commissioner of Indian affairs, in 1933. In her impeccably typed letter, Margaret told him, "I am an Indian girl and a graduate from Sherman Institute. . . . I was sent out to that school to get an education. When I graduated I found I could not get any other job but as a housekeeper. Any girl knows how to do that sort of work I'm sure. My four years wasted. I found I could have accomplished more if I had attended a regular public high school." ${ }^{\prime 99}$ Margaret also told Collier how her family had lost their land and become destitute. Her grandmother had sold the family's land, and they were living off money from its sale. When her grandmother died, however, Margaret's family could not get the rest of the money, because her grandmother had not left a will. Margaret lamented, "The reason why we Indians in the middle part of California are backward is because we have nothing to get started with. The little we have doesn't amount to anything. We have no money to go to college to be somebody. Why doesn't somebody give us a break?" She explained further to Collier, "I am working here in Hollywood as a housekeeper. My salary is twenty a month. My ambition was to become a nurse; as I am lacking some credits, I can't get in any nursing school. That means I just have to go back and start my four years over again." She concluded, "This is just a glimpse of one Indian family, but there are many more in California." ${ }^{90}$

Collier proved to be of little help to Margaret. ${ }^{91}$ She continued to work throughout the 1930 s as a housekeeper. Later, she became pregnant and married but separated from her husband. When she could not find a place to board the baby while she worked, she decided to leave the child with her mother and make her mother its legal guardian. Margaret remained resentful that after years of boarding school, she could not find work other than domestic service. In 1941, according to Van Every, a man came into her placement center and told her that "[Margaret] ... and [her friend] [A.] ... are violent in their attitude toward our office.... They lose no opportunity to make remarks and criticisms and say that we keep Indian girls down." ${ }^{\prime 2}$ Finally in 1942 Margaret was able to complete a course at the hospital and gain a temporary position there. ${ }^{93}$

Many young women defied the matrons and their employers specifically 
over the gender roles and sexual standards they sought to instill in the girls. Rather than abiding by the outmoded Victorian mode that was often promoted in the schools, many of the girls embraced the new freer sexual expression for women that had begun to appear in American popular culture during the 1910s. ${ }^{94}$ New hairstyles, music, movies, and books lured the young women away from boarding-school fare. Elsie told Matron Van Every that "she wished to stay a while [in a new job] until she got some things she needed including a permanent wave." ${ }^{95}$ While hospitalized, Sarah asked Van Every for "two new movie magazines and one Western Romance. . . . If you would please send them to me. Is all I would like to have."96

The matrons and some of their employers tried to channel the young Indian women's sexuality into appropriate channels-marriage to respectable, Christian Indian men who were also presumably on the road to assimilation. In 1929, Matron Royce lamented that "the lack of moral standards among the majority of the girls cause $[s i c]$ great social difficulties; many embarrassing moral questions have been presented during my ten years supervising Indian Welfare, in the San Francisco Bay District; unmarried girls becoming pregnant, girls leaving employment to live with men, married ones leaving wife or husband for others and the contracting of venereal diseases." Royce tried to prevent such outcomes by inviting desirable young men-presumably Indian men - to parties and dances. She reported to her supervisor in 1929, "Special interest has been taken in the young men this year. Many have been called upon and invited and encouraged to call at my home. Their habits have been investigated and if found to be proper associates for the girls they were invited to the social affairs." ${ }^{\prime 97}$

Royce also used other means to block young Indian women from socializing with men she deemed unsuitable, as in the case of "Etta," who wrote to her father to protest "against Mrs. Royce having anything to do with her while she is working in Oakland." Etta's father then complained to BIA authorities; Superintendent Snyder countered, however, that it was Royce's job "to look after the interests of young Indian women who work in the coast cities. ... While [Etta] may be 22 years of age," he noted, "I do not think she should resent any supervision that Mrs. Royce may have over her." ${ }^{98}$ Etta and her father disagreed, however. Her father wrote to Royce in 1925, "I wish you would leave [Etta] alone. She's all right when you leave her alone, she old enough to look after her self." Royce seemed to object to the man that Etta had chosen to marry. "If that boy love her and she loves him leave them alone," Etta's father admonished Royce. "We can't pick out her husband and his wife for them so just leave them alone, let them get married if they love each others [sic]." Etta's father noted a double standard: "These people here just leave the young pale- 
face alone, they don't but in when they want to get married, they just let them get married. I thought any people I mean Indians could get married any time as long as they're old enough. If they have their folks consent, But I'm mistaken I see $[$ sic $] .{ }^{\prime 99}$

Royce's efforts seem to have made little difference. For one thing, as noted by Lombard, there were about five Indian women to every Indian man in the Bay Area. ${ }^{100}$ Even had all these men met Royce's criteria as suitable mates for the young Indian women, clearly there were not enough men to go around. Moreover, freed from the constraints of the boarding schools and able to evade their employers and the matrons, many young women seemed to revel in new social opportunities and the chance to flirt and socialize with young men. Some of the young women's relationships culminated in formal or commonlaw marriage, to Indians and non-Indians, and almost always outside their tribes. Ruth married a Portuguese man in 1934. Wynona "married a white man with the Radio-Post at San Francisco Beach." Bernice, a Winnebago, began living with a "Negro" in $1938 .{ }^{101}$ Those young Indian women who did link up with Indian men from outside their communities reinforced the trend that had already begun with the formation of boarding schools - the formation of a pan-Indian identity — and that increased during and after World War II as more Indians moved to urban centers. ${ }^{102}$

Many other young Indian women became single mothers as a result of their sexual relationships in the city. Of the ninety-seven case files I studied, more than one-quarter of the young women became pregnant or already had children while working as domestic servants. Only a couple of these women were married. While the matrons and employers generally viewed this as a sign of the young women's immorality (or their own failed mission to "civilize" and "assimilate" them), within their own Indian communities, it is unlikely that the young Indian women experienced the same degree of disapproval and judgment for becoming single mothers. Among the Pomos, for example, no stigma seems to have been attached to young Pomo women who returned from the city pregnant. ${ }^{103}$

Given the tense climate over their work and leisure in the city, it is no surprise that many of the young women dealt with their conflicts with employers and matrons by simply quitting or running away from their jobs. The files reveal that nine young women abruptly quit their service and that twelve ran away from their positions, a total of almost 22 percent of all the young women I studied. Many young Indian women stayed with an employer only a few months (and in some cases for a period of just days or weeks) before moving on to another employer, returning home for the summer or a brief period, or absconding. On the outing form of "Vera," a Western Shoshone, for 
example, the outing matron wrote, "In 1928 ran away May 19th, unmanagable [sic], detention home May 22." Two years later, the matron added, "In Sept. 1930 Entered Chemawa Indian School. Ran away from same. Placed with Mrs. Bruzzone, Ala[meda]. [A]cted very ugly, impudent and lady would not even keep her over night." 104

The frequency with which young Indian women ran away from their domestic service jobs demonstrates another important difference between their employment and that of other women who worked as servants. On the one hand, it suggests that at least some of the young women felt a greater sense of compulsion in their jobs and thus a greater need to run away than did other servants. As Vera's experience reveals, young Indian women could even be sent to detention homes for running away. The BIA's outing program thus represented a more paternalistic work situation than other domestic service arrangements.

On the other hand, the fact that large numbers of young Indian women left their jobs after only a few months indicates that they had or felt they had greater options; young Indian women had homes and communities (impoverished though they were) to which they could return or networks of other young Indian women with which they could connect. Other forms of seasonal employment—such as picking hops—also appealed more than continuous employment in the city. As Victoria Patterson puts it, "most [Pomo] girls chose to jeopardize their jobs [in the city] every summer by returning to Mendocino County for the hop season, that time of riverside trysts, easy living, and wages that equaled ten months of dreary housework in someone else's house."105

Finally, this phenomenon suggests that the young Indian women had not imbibed the capitalist ethos of the assimilation program. Both Lombard and Colson remarked, with a hint of disappointment, that not one of the young Pomo women they observed and interviewed in the late 1930s had made domestic service a career. ${ }^{106}$ Clearly, the outing matrons and the white women employers were also perturbed that they could not get most of the young Indian women to settle down in one position or use their employment as a steppingstone to a "respectable" marriage.

It is tempting to end the story of these young Indian women here as a triumphant tale of a group of women marginalized by their class, race, and gender who managed to pull one over on their would-be oppressors. Within the context of feminist history, we could celebrate these young women's entrance into wage labor and their pursuit of new leisure activities and sexualities as liberatory. Alternatively we could interpret their experience within the context of recent American Indian history and trumpet the ability of these young Indian women to resist assimilation. Yet for the young Indian women "outed" to 
domestic service, concepts such as liberation and resistance must be tempered with a view of the larger forces of colonialism that constrained their lives.

The assimilation project may have broken down along this domestic frontier, but the long tentacles of the BIA still reached the young Indian women. When some young Indian women servants-roughly one-quarter of my sample-became pregnant and had children, it is evident that the BIA and its agents still had the upper hand. Having a child while working as a servant often presented an overwhelming challenge to young Indian women, many of whom had delivered their babies, through the arrangement of the outing matrons, at the Salvation Army Rescue Home. One wonders how Jane, unmarried, who bore a baby on December 13, 1928, cared for him after she began work again on January 30, 1929. ${ }^{107}$

Some young Indian women left their children back home with relatives. "Mary," a Pomo, had two children whom she left with her mother while she went to work as a domestic servant for nine months of the year. Apparently, Mary came home in the summers, where she could find work picking hops and see her children. ${ }^{108}$ Some young Indian women found this situation intolerable. When "Stella" had a baby, she left it with its grandmother, but eventually Stella left her employer and returned to her home near Ukiah. A field nurse there lamented to Royce, "So another effort to help her has gone wrong. I still believe the girl wants to do right. It was a lot to expect of her to leave her baby and all her relatives to go out alone to earn a living." 109 Interestingly, during an era when most white women reformers pushed for mother's pensions so that poor women - at least white women - could stay at home with their children, white women in the BIA deemed an Indian woman who came home to take care of her baby as "gone wrong." 110 The field matron's comment suggests a widespread assumption among many white women who worked with Indian peoples that an Indian woman's place was in the (white woman's) home as servant. To such white women maternalists, a young Indian woman who stayed home with her baby and "all her relatives" had not properly imbibed the individualist capitalist ethos promoted by assimilation.

Other young Indian women boarded their children out while they worked. "Ethel," a Paiute, "arrived in Oakland, July 23-1931 With small baby girl." Royce placed Ethel as a domestic and put her baby in a boarding home, but admitted to a field matron among the Paiutes, "I am sure I do not know how we are going to pay for the baby's board, for I fear [Ethel] cannot make enough to support herself and child. The price of the baby's board is \$25.00, and [Ethel] has started to work for that amount." ${ }^{111}$ Indeed, boarding out one's baby while working was a costly proposition and illustrated that young Indian women were subject to the phenomenon of what Sau-ling Wong calls "diverted moth- 
ering," whereby "time and energy available for mothering are diverted from those who, by kinship or communal ties, are their more rightful recipients" to care for the employers' children instead. ${ }^{112}$

The matrons put considerable pressure on some Indian mothers (five of the twenty-five Indian mothers) to give their children up for adoption or to put them in institutions. The case of "Nellie" is a poignant one. When Van Every first began her work, she encountered Nellie, who had a twenty-two-monthold boy, "Sammy," who lived with a Mrs. Upson while Nellie worked. Nellie had since married and had another baby. With former matron Traxler, Van Every called on Nellie and wrote in her file that "she says that she still wishes to have the baby [Sammy] with her, but that her husband has no steady work." Her husband "does not object to having the child brought home if [Nellie] wishes it. But there is not enough money for their own expenses." Nellie was emphatic that "she does not wish to place the child [Sammy] in an institution."

Despite Nellie's reluctance to part with her son, Traxler and Van Every called upon Mrs. Marie White of the California Children's Home Society. "We gave the account of [Sammy], son of [Nellie], urging steps to be taken immediately in giving [Sammy] a home rather than longer continuing with Mrs. Upson, who is getting too old to care for him longer," Van Every reported. "Mrs. White said that unless [Nellie] can assume the responsibility of the child or some of the girls' family can see the child thru, the child must be adopted out. The mother must give over the case of the child to the Child placing agency and sign a relinquishment or a consent before an agency can do the work need[ed] to take over the case.... Mrs. White asked us to advise [Nellie] that we had talked with her and ask for [Nellie]'s full cooperation in the case."

Traxler and Van Every then went to visit Nellie again. By now, economic exigencies seem to have convinced Nellie she had no other choice but to give up her son. "When asked what she intended doing about [Sammy] she said that she would have to let him be adopted out," Van Every reported. "We told her of Mrs. Marie White of the Children's Home Society of California and of the work the Society did. She seemed to understand the steps necessary to placing [Sammy] in a Home. She agreed that she would cooperate fully with Mrs. White." A few weeks later, Van Every learned that "[Nellie] is expecting another baby and is quite willing to give [Sammy] up, not knowing what else to do about him. She signed the relinquishment papers." 113

Interestingly, the records reveal that the matrons and the adoption agencies with which they worked did not deem all the children of Indian women as suitable for adoption. In some cases, the child welfare agencies discouraged removing children who particularly looked "Indian" from the young women for adoption. Van Every revealed, "The Child Placement Bureau has had Indian 
placements to make in the past and has found them very difficult, in fact impossible, especially when the child is of such Indian cast of features." 114

Alternatively, the matrons and other BIA officials sought to have some children removed from their Indian mothers and institutionalized, just as many of them had been parted from their own parents to attend boarding schools or go to work in other families' homes. Losing their children in such a way was often a source of intense pain and anguish for the young women. For example, Etta (the woman whose father had protested against Royce's intervention into her relationship) had been separated from her parents and raised at the Carson Indian School. When authorities removed her four children and sought to place the oldest, a six-year-old boy, at the Carson school, Etta objected strenuously. A probation officer reported that Etta "is most unwilling for this placement, stating that she had been very unhappy there and that she could not possibly consider placing her child there." 115 Despite Etta's wishes, Royce conspired with Superintendent Snyder to place Etta's son at the Carson school. Royce, in fact, declared that Etta's "wishes should not be considered in this case, as she is incapable of judging what is best for her boy."

Authorities not only removed Etta's children but took steps as well to have her placed in a mental institution, claiming that a psychological test had "rated [her] as borderline, mental age 11 years." The matrons' outing records reveal that three other Indian women who had several children out of wedlock and resisted officials' attempts to remove their children were also eventually committed to mental institutions. ${ }^{116}$ These cases are a sobering reminder of the high cost that these young Indian women paid for their attempts to live out from under the control of the BIA.

Thus, this is not a simple story of women achieving liberation by pursuing wage labor and embracing modern gender roles. Nor is it merely an uplifting tale of Indian resistance to assimilation. Instead it is an account complicated by not just the legacy of conquest but the ongoing practice of colonialism, now masquerading in the guise of assimilation policy. The households in which young Indian women worked became intimate theaters of colonialism where the roles of gently guiding white mistress and obedient and deferent Indian servant had been scripted and were expected to be played out. This domestic frontier was meant not merely to reflect the new colonial order imposed upon Indian peoples but also to reproduce and perform it in a kind of long-running theatrical production.

However, Indian women domestic servants, as they migrated from their rural homes and communities to the urban Bay Area or from boarding school to workplace, did not passively accept their assigned role in the colonial 
script—as nameless laborers to be made useful in the "New World Domestic Order." These young Indian women had their own agendas; they wanted to immerse themselves in modern urban life, enjoy the company of other young Indian women, meet men, and use their jobs in the city as steppingstones out of or a temporary respite from the poverty and discrimination they faced in their home communities. Ultimately, for many if not most of the young Indian women who worked in the Bay Area, the period of service constituted a temporary period in their lives. (Lombard found that of all the Pomo women who went to work in the Bay Area, all but one or two eventually returned home.) $)^{117}$ For some of these young Indian women, working on the domestic frontier in the Bay Area was a carefree adventure, almost a rite of passage, between boarding school (in many cases) and returning to their reservations or rancherias. For other servants, like Etta, working and living on this domestic frontier was a humiliating and harrowing experience that demonstrated the pervasive power of the BIA.

For officials with the BIA, colonization proved to be as incomplete and elusive along this domestic frontier as it did in other contact zones between colonizers and indigenous people. Rather than assimilating what the BIA regarded as appropriate work ethics and gender norms, most of these young Indian women made neither a career of domestic service nor a BIA-approved marriage. The BIA, therefore, did not succeed in solving the "Indian problem," of winning the hearts, minds, and souls of these young Indian women. It settled instead for continuing to exercise a degree of paternalistic control over them. Thus most of the young Indian women servants experienced only fleeting moments of self-determination over their own lives. As May wrote to Amelia, "I'm going to try to be a good girl, if I can make it \& try to enjoy myself. It seems though I've lost all my happiness. Ever since I came back here. I hope to be my self some times." 118

\section{NOTES}

1. P. Ar. to Van Every, October 30, 1934, chronology, P. Ar. file, Box 1, Relocation, Training, and Employment Assistance Case Records, 1933-1946, Outing Girls, Record Group (RG) 75, Bureau of Indian Affairs (BIA), California Sacramento Agency, National Archives and Records Administration, Pacific Region, San Bruno, California (hereafter Outing Records). These records contain sensitive material that may embarrass or offend the Indian women or their descendants. Therefore, to respect the identity of these women, their families, and their descendants, I have used pseudonyms for each young woman followed by her tribal identity, if identified in the records. The notes give the initials of each young woman. 
2. For general coverage of the decline of white, native-born women in domestic service and the predominance of nonwhite women in the field, see Ellen Carol DuBois and Lyn Dumenil, Through Women's Eyes: An American History with Documents (Boston: Bedford/St. Martin's, 2005), 285, 543. For more on domestic service specifically in the early twentieth century, see Phyllis Palmer, Domesticity and Dirt: Housewives and Domestic Servants in the United States, 1920-1945 (Philadelphia: Temple University Press, 1989).

3. Judith Rollins, Between Women: Domestics and Their Employers (Philadelphia: Temple University Press, 1985), 6-7. Other works on domestic service include Faye Dudden, Serving Women: Household Service in Nineteenth-Century America (Middletown, CT: Wesleyan University Press, 1983); Daniel E. Sutherland, Americans and Their Servants: Domestic Service in the United States from 1800 to 1920 (Baton Rouge: Louisiana State University Press, 1981); Elizabeth Clark-Lewis, Living In, Living Out: African American Domestics in Washington, D.C., 1910-1940 (Washington, DC: Smithsonian Institution Press, 1994); and Palmer, Domesticity and Dirt.

4. For more on the removal of Indian children to boarding schools, see my articles, "A Battle for the Children: American Indian Child Removal in Arizona in the Era of Assimilation," Journal of Arizona History 45, no. 1 (Spring 2004): 31-62; and "The Great White Mother: Maternalism and American Indian Child Removal in the American West, 1880-1940," in One Step Over the Line: Toward an Inclusive History of Women in the North American Wests, ed. Elizabeth Jameson and Sheila McManus (Calgary: University of Calgary Press, forthcoming). Australia followed a similar policy of removing indigenous girls to be trained in institutions and then apprenticed out to white families. See Victoria K. Haskins, One Bright Spot (New York: Palgrave, 2005). For more on outing programs and training girls for domestic service, see Alice Littlefield, "Learning to Labor: Native American Education in the United States, 1880-1930," in The Political Economy of North American Indians, ed. John H. Moore (Norman: University of Nebraska Press, 1993), 43-59; K. Tsianina Lomawaima, "Domesticity in the Federal Indian Schools: The Power of Authority over Mind and Body," American Ethnologist 20, no. 2 (May 1993): 227-240.

5. For some significant works on gender and colonialism within intimate settings, see Ann Laura Stoler, Carnal Knowledge and Imperial Power: Race and the Intimate in Colonial Rule (Berkeley: University of California Press, 2002); Margaret Strobel, Gender, Sex, and Empire (Washington, DC: American Historical Association, 1994); Julia Clancy-Smith and Frances Gouda, eds., Domesticating the Empire: Race, Gender, and Family Life in French and Dutch Colonialism (Charlottesville: University of Virginia Press, 1998); Margaret Jolly and Martha Macintyre, eds., Family and Gender in the Pacific: Domestic Contradictions and the Colonial Impact (Cambridge: Cambridge University Press, 1989).

6. Outing Records. These records do not reveal the experiences of all American 
Indian women who worked as domestic servants in the Bay Area. Many did not use the YWCA's placement service. For example, Mabel McKay, a Pomo healer and basketmaker, worked for a time as a maid for a madam in a brothel. See Greg Sarris, Mabel McKay: Weaving the Dream (Berkeley: University of California Press, 1994), 64.

7. For more on life among the Pomos up to 1900, see Victoria Patterson, "Change and Continuity: Transformations of Pomo Life," Expedition 40, no. 1 (1998): 3-15. Greg Sarris's Keeping Slug Woman Alive: A Holistic Approach to Indian Texts (Berkeley: University of California Press, 1993) and Mabel McKay also contain much historical and ethnographic information throughout. The Bole Maru movement was known as the Bole Hesi among the eastern Pomos.

8. According to Greg Sarris and Victoria Patterson, ethnographers designated several indigenous groups of north-central California natives as "Pomos," although they spoke different (but related) languages. See Sarris, Keeping Slug Woman Alive, 8; Victoria Patterson, "Indian Life in the City: A Glimpse of the Urban Experience of Pomo Women in the 1930s," California History 71 (Fall 1992): 453, n.1.

9. Clifford E. Trafzer and Joel R. Hyer, "Exterminate Them": Written Accounts of the Murder, Rape, and Slavery of Native Americans during the California Gold Rush, 18481868 (East Lansing: Michigan State University Press, 1999), 140.

10. Sarris, Keeping Slug Woman Alive, 9-10. Scholars estimate that California Indians once numbered about 300,000 before European contact. Under Spanish and then Mexican rule, their numbers declined to 150,000, but within just ten years of American conquest, their population had dipped 80 percent to 30,00o. See Albert Hurtado, Indian Survival on the California Frontier (New Haven: Yale University Press, 1988), 1. Sherburne F. Cook carried out the most significant demographic studies of California Indians. As one example of his work, see The Population of the California Indians, 1769-1970 (Berkeley: University of California Press, 1976). For more on the devastating impact of American conquest on California Indians, see Tomás Almaguer, Racial Fault Lines: The Historical Origins of White Supremacy in California (Berkeley: University of California Press, 1994), 107-50; and James Rawls, Indians of California: The Changing Image (Norman: University of Oklahoma Press, 1984), 44-217.

11. Elizabeth Colson, "A Study of Acculturation among Pomo Women," (MA thesis, University of Minnesota, 1940), 37; Patterson, "Change and Continuity."

12. Colson, "A Study of Acculturation," 35-36, 44; Patterson, "Change and Continuity."

13. Colson, "A Study of Acculturation," 61; Colson, Autobiographies of Three Pomo Women (Berkeley: University of California Department of Anthropology, 1974), 27.

14. Colson, "A Study of Acculturation," 37.

15. Juliette Lombard, "The Migration of Women from the Ukiah Valley in California to the San Francisco Bay Region," (MA thesis, Columbia University, 1942), 18, 17; see also Colson, Autobiographies, 28.

16. Annual Meeting and Report of the Women's National Indian Association 
(Philadelphia: Women's National Indian Association, 1883), 10, 11. See also Valerie Mathes, "Nineteenth-Century Women and Reform: The Women's National Indian Association," American Indian Quarterly 14 (1990): 1-18; Mathes, Helen Hunt Jackson and Her Indian Reform Legacy (Austin: University of Texas Press, 1990); and Helen Wanken, “'Woman's Sphere' and Indian Reform: The Women's National Indian Association, 1879-1901” (PhD diss., Marquette University, 1981).

17. Frederick Hoxie, A Final Promise: The Campaign to Assimilate the Indians, 1880-1920 (Lincoln: University of Nebraska Press, 1984).

18. Course of Study of the Indian Schools of the United States, Industrial and Literary (Washington, DC: U.S. Government Printing Office, 1901), 86-87. Included in Box 1, Folder 13, MS 120 Papers of Estelle Reel, Eastern Washington State Historical Society, Northwest Museum of Arts and Culture, Spokane, Washington.

19. Carl Moore, Supervisor of Indian Education, to Commissioner of Indian Affairs, November 21, 1929, Box 3, Folder: Outing Center-Berkeley, Supervisor of Indian Education, Administrative Subject Records, 1929-1932, RG 75, BIA California, NARA, San Bruno.

20. Course of Study of the Indian Schools.

21. Philip J. Ethington, The Public City: The Political Construction of Urban Life in San Francisco, 1850-1900 (New York: Cambridge University Press, 1994), 2.

22. Shirley Ann Wilson Moore, To Place Our Deeds: The African American Community in Richmond, California, 1910-1963 (Berkeley: University of California Press, 2000); Gretchen Lemke-Santangelo, Abiding Courage: African American Migrant Women and the East Bay Community (Chapel Hill: University of North Carolina Press, 1996).

23. For domestic service in the San Francisco Bay Area, see Evelyn Nakano Glenn, Issei, Nisei, War Bride: Three Generations of Japanese American Women in Domestic Service (Philadelphia: Temple University Press, 1986), 105-109. For more on the restrictions on Asian immigration, see Ronald Takaki, Strangers from a Different Shore: A History of Asian Americans (Boston: Little, Brown, 1989). For more on the repatriation of Mexican Americans in the 1930s, see Francisco Balderrama and Raymond Rodriguez, Decade of Betrayal: Mexican Repatriation in the 1930s (Albuquerque: University of New Mexico Press, 1995).

24. Frederic Snyder to Commissioner of Indian Affairs, January 14, 1930, Box 3, Folder: "Outing Center-Berkeley," Supervisor of Indian Education, Administrative Subject Records, 1929-1932, RG 75, BIA California, NARA, San Bruno.

25. Palmer estimates that between 1920 and 1930,11-15 percent of employed American Indian women were working as domestics (Domesticity and Dirt, 12, 67). Brief examples of work on Indian women domestic servants include Patterson, "Indian Life in the City," 402-11, 453; and Robert A. Trennert, Jr., The Phoenix Indian School: Forced Assimilation in Arizona, 1891-1935 (Norman: University of Oklahoma Press, 1988), 52-54, 70-73. 
26. See, for example, Theda Perdue, Cherokee Women: Gender and Culture Change, 1700-1835 (Lincoln: University of Nebraska Press, 1998); Lillian Ackerman, A Necessary Balance: Gender and Power among Indians of the Columbia Plateau (Norman: University of Oklahoma Press, 2003); Karen Anderson, Chain Her by One Foot: The Subjugation of Women in Seventeenth-Century New France (New York: Routledge, 1991); Carol Devens, Countering Colonization: Native American Women and Great Lakes Missions, 1630-1900 (Berkeley: University of California Press, 1992).

27. Philip J. Deloria, Indians in Unexpected Places (Lawrence: University of Kansas Press, 2004). For several books that look at American Indians' encounters with modern wage labor and economic development, see Colleen O'Neill, Working the Navajo Way: Labor and Culture in the Twentieth Century (Lawrence: University of Kansas Press, 2005); Brian Hosmer and Colleen O’Neill, Native Pathways: American Indian Culture and Economic Development in the Twentieth Century (Boulder: University Press of Colorado, 2004); Alice Littlefield and Martha C. Knack, eds., Native Americans and Wage Labor: Ethnohistorical Perspectives (Norman: University of Oklahoma Press, 1996); James B. LaGrand, Indian Metropolis: Native Americans in Chicago, 1845-75 (Urbana: University of Illinois Press, 2002).

28. For some of the first works to critique earlier conceptions of the frontier and to redefine it, see Patricia Nelson Limerick, The Legacy of Conquest: The Unbroken Past of the American West (New York: Norton, 1987); Richard White, The Middle Ground: Indians, Empires, and Republics in the Great Lakes Region, 1650-1815 (New York: Cambridge University Press, 1991).

29. Janet Henshall Momsen, "Maids on the Move: Victim or Victor," in Gender, Migration and Domestic Service, ed. Janet Henshall Momsen (New York: Routledge, 1999), 11.

30. Glenn, Issei, Nisei, War Bride, 9.

31. Rhacel Salazar Parreñas, Servants of Globalization: Women, Migration and Domestic Work (Stanford: Stanford University Press, 2001); Momsen, ed., Gender, Migration and Domestic Service; Pierrette Hondagneu-Sotelo, Doméstica: Immigrant Workers Cleaning and Caring in the Shadows of Affluence (Berkeley: University of California Press, 2001).

32. Stoler, Carnal Knowledge, 9; Ann Laura Stoler, "Tense and Tender Ties: The Politics of Comparison in North American History and (Post) Colonial Studies," Journal of American History 88 (2001): 830.

33. Cato Sells to Superintendent Royce, September 12, 1918, Box 10, Investigative Records of Colonel L. A. Dorrington, Special Agent, 1913-1923, Bureau of Indian Affairs, Nevada, RG 75, NARA, San Bruno.

34. Royce to Supervisor Holst, July 23, 1929, Box 1, Folder: "Los Angeles Berkeley Outing Centers," Supervisor of Indian Education 1928-1929; Royce to Moore, June 10, 1930, Box 3, Folder: “Outing Center-Berkeley," Supervisor Of Indian Education, 
Administrative Subject Records, 1929-1932; both in RG 75, BIA California, NARA, San Bruno. See also Outing Records. The BIA also established a similar outing program in the Los Angeles area, also presided over by an outing matron. See Box 1, Folder 15-0: "Outing Los Angeles, Supervisor of Indian Education 1928-1929, RG 75, BIA California, NARA, San Bruno.

35. Carl Moore, Supervisor of Indian Education, to Commissioner of Indian Affairs, November 21, 1929, Box 3, Folder: Outing Center-Berkeley, Supervisor of Indian Education, Administrative Subject Records, 1929-1932, RG 75, BIA California, NARA, San Bruno.

36. Lombard, "Migration of Women," 24-25.

37. Lombard, "Migration of Women," 10; Patterson, "Indian Life in the City," 405.

38. Lombard, "Migration of Women," 25; Patterson, "Indian Life in the City," 408.

39. Royce to Snyder, April 9, 1930, Box 3, Folder: “Outing Center-Berkeley," Supervisor Of Indian Education, Administrative Subject Records, 1929-1932; both in RG 75, BIA California, NARA, San Bruno.

40. Victoria Haskins notes a similar geometry between Aboriginal domestic servants, white women employers, and the state's agencies in Australia, where "white mistresses, being positioned between the state and the Aboriginal women, were in fact intermediaries involved in an intimate, day-to-day experience of the practice of the state's Aboriginal policy." See her dissertation, "My One Bright Spot: A Personal Insight into Relationships between White women and Aboriginal Women under the NSW Aborigines Protection Board Apprenticeship Policy, 1920-1942," (PhD diss., University of Sydney, 1998), quote p. 59. See also Haskins, One Bright Spot.

41. See Van Every to Bertha Eckert, National Board, YWCA, October 5, 1937, J.B. file, Box 1, Outing Records; list of Indian Girl's Work Committee, April 15, 1942, courtesy of YWCA of Oakland. The YWCA was, according to Phyllis Palmer, "the women's organization that was most persistently concerned with the problems of domestic service." Thus it is no surprise that the outing matrons had connections with the YWCA and some sympathy for the young domestic servants. See Palmer, Domesticity and Dirt, 113.

42. Murphey to Van Every, November 26, 1934, V.B. file, Box 1, Outing Records.

43. Linda Gordon, Pitied but Not Entitled: Single Mothers and the History of Welfare (Cambridge, MA: Harvard University Press, 1994), 55. See also Sonya Michel, Children's Interests/Mother's Rights: The Shaping of America's Child Care Policy (New Haven, CT: Yale University Press, 1999); Gwendolyn Mink, The Wages of Motherhood: Inequality in the Welfare State, 1917-1942 (Ithaca, NY: Cornell University Press, 1995); Molly Ladd-Taylor, Mother-Work: Women, Child Welfare, and the State, 1890-1930 (Urbana: University of Illinois Press, 1994); Theda Skocpol, Protecting Soldiers and Mothers: The Political Origins of Social Policy in the United States (Cambridge, MA: Belknap Press of Harvard University Press, 1992). For more on white women's maternalism toward Indian women, see my article, "The Great White Mother." 
44. See especially Gordon, Pitied but Not Entitled.

45. David Wallace Adams, Education for Extinction: American Indians and the Boarding School Experience, 1875-1928 (Lawrence: University of Kansas Press, 1995), 82, 83. Cathleen Cahill, “'Only the Home Can Found a State': Gender, Labor, and the United States Indian Service, 1869-1928” (PhD diss., University of Chicago, 2004), 161, 387. Cahill also believes that the BIA served as an agency in which women were encouraged to enact their maternalist sensibilities. See especially 16-19, 77-82, 227-77.

46. Cato Sells to Superintendent Royce, September 12, 1918, Box 10, Investigative Records of Colonel L. A. Dorrington, Special Agent, 1913-1923, BIA, Nevada, RG 75, NARA, San Bruno.

47. Palmer, Domesticity and Dirt, 53.

48. Hondagneu-Sotelo, Doméstica, 22-23.

49. Lombard, "Migration of Women," 30.

50. A. Be. to Royce, October 6, 1931, A. Be. file, Box 1, Outing Records.

51. M. Bl. to Royce, August 12, 1930, M. Bl. file, Box 1, Outing Records.

52. Patterson, "Indian Life in the City," 410; Lombard, "Migration of Women," 32-33; Colson, "A Study of Acculturation," 85-86.

53. O'Neill, Working the Navajo Way, 13-14; see also 29. In addition, see Hosmer and O’Neill, eds., Native Pathways; Martha C. Knack and Alice Littlefield, "Native American Labor: Retrieving History, Rethinking Theory," in Native Americans and Wage Labor, 26; Harold Prins, "Tribal Network and Migrant Labor: Mi'kmaq Indians as Seasonal Workers in Aroostook's Potato Fields, 1870-1980," in Native Americans and Wage Labor, 51; LaGrand, Indian Metropolis, 25.

54. Quoted in Lombard, "Migration of Women," 21; for lack of employment and prejudice see 14-21; Patterson, "Indian Life in the City," 403.

55. Chronology for I. B., March 5, 1939, I. B. file, Box 1, Outing Records.

56. Van Every to Roy Nash, Superintendent, Sacramento Indian Agency, April 29, 1940, Fr. A. file, Box 1, Outing Records.

57. J. J. to Royce, September 23, 1931, J. J. file, Box 2, Outing Records.

58. E. J. file, Box 2, Outing Records.

59. Chronology for J. B., October 13, 1937, J. B. file, Box 1, Outing Records.

60. Patterson, "Indian Life in the City," 410; A YWCA promotional brochure of 1930 boasts that sixty "individual Indian girls attended winter and summer programs, clubs, parties, Sunday afternoon services and out-door expeditions." See also Oakland YWCA, "A Review of the year 1939," 13-14. Both of these items are courtesy of the Oakland Public Library.

61. M. to A., March 23, 1929, M. J. file, Box 2, Outing Records.

62. A. A. file, Box 1, Outing Records.

63. On urban pan-Indianism, see LaGrand, Indian Metropolis.

64. M. and A. D. to Royce, n.d. (ca. 1929), A. D. file, Box 2, Outing Records. 
65. M. to A., March 23, 1929, M. J. file, Box 2, Outing Records.

66. Files of Ev. A., El. A, and P. Ar., Box 1, Outing Records.

67. Taft to Traxler, November 13, 1933, H. E. file, Box 2, Outing Records.

68. I. S. file, Box 4, Outing Records.

69. El. A. file, Box 1, Outing Records.

70. See Clark-Lewis, Living In, Living Out.

71. V. G. file, Box 2, Outing Records. For more on white women's expectations of deference, see Rollins, Between Women, 156-170, 178-203; Mary Romero, Maid in the U.S.A. (New York: Routledge, 1992), 97-119.

72. Grace Cresap to Royce, July 3, 1930, Box 1, Folder: "Outing Contracts, Outing Girls, 1930," Records of the Berkeley Outing Matron and Placement Officer, 1916-1933, RG 75 BIA California, NARA, San Bruno.

73. S. M. to Van Every, July 19, 1935, S. A. M. file, Outing Records.

74. G. P. file, Box 3, Outing Records.

75. F. C. to Royce, n.d., Box 1, Folder: “Outing Contracts, Outing Girls, 1932," Records of the Berkeley Outing Matron and Placement Officer, 1916-1933, RG 75 BIA California, NARA, San Bruno.

76. F. C. to Royce, n.d. Box 1, Folder: "Outing Contracts, Outing Girls, 1932," Records of the Berkeley Outing Matron and Placement Officer, 1916-1933, RG 75 BIA California, NARA, San Bruno.

77. V. F. to "Dearie," May 3, 1928, V. F. file, Box 2, Outing Records.

78. Mrs. Harrington to Royce, n.d., Box 1, Folder: "Outing Contracts, Outing Girls, 1932," Records of the Berkeley Outing Matron and Placement Officer, 1916-1933, RG 75 BIA California, NARA, San Bruno.

79. Royce to Mrs. C. B., October 24, 1932, A. Be. file, Box 1, Outing Records.

8o. Fl. A. file, Box 1, Outing Records.

81. Fr. A. file, Box 1, Outing Records.

82. Royce to Mrs. Cleland, Ukiah, July 12, 1927, F. E. file, Box 2, Outing Records.

83. Chronology, March 18, 1937, P. Ar. file, Box 1, Outing Records.

84. Chronology, March 22, 24, and 26, 1937, P. Ar. file, Box 1, Outing Records.

85. Oakland YWCA, "A Review of the Year 1939," 13-14.

86. Royce to Emmett McNeilly, superintendent of Western Shoshone Agency, February 16, 1929, A. H. file, Box 2, Outing Records.

87. Royce to McNeilly, February 16, 1929, A. H. file, Box 2, Outing Records.

88. Superintendent Frederic Snyder to P. An., August 17, 1927, P. An. file, Box 1, Outing Records.

89. I. T. to John Collier, August 6, 1933, I.T.(S.) file, Box 4, Outing Records. 90. Ibid.

91. Collier to I. T., August 24, 1933, I.T.(S.) file, Box 4, Outing Records. 92. Chronology, October 13, 1941, I.T.(S.) file, Box 4, Outing Records.

93. Chronology, I.T.(S.) file, Box 4. 
94. Many scholars have noted that the boarding schools promoted nineteenthcentury Victorian-style gender roles for girls. As just one example, see Tsianina Lomawaima, They Called it Prairie Light: The Story of Chilocco Indian School (Lincoln: University of Nebraska Press, 1994).

95. Chronology, March 6, 1938, Fl. A. file, Box 1, Outing Records.

96. S. C. to Van Every, July 18, 1936, S. C. file, Box 1, Outing Records.

97. Quoted in Carl Moore, Supervisor of Indian Education, to Commissioner of Indian Affairs, November 21, 1929, Box 3, Folder: “Outing Center-Berkeley," Supervisor of Indian Education, Administrative Subject Records, 1929-1932, RG 75, BIA California, NARA, San Bruno.

98. Superintendent Snyder to Daniel Robertson, Lovelock, Nevada, May 15, 1925, G. W. file, Box 4, Outing Records.

99. J. W. to Royce, July 6, 1925, G. W. file, Box 4, Outing Records.

100. Lombard, "Migration of Women," 30.

101. S. A. M. file, Box 1; A. Be. file, Box 1; B. L. file, Box 3, Outing Records.

102. See LaGrand, Indian Metropolis, especially 161-182.

103. Lombard, "Migration of Women," 35, 38.

104. D. H. file, Box 2, Outing Records.

105. Patterson, "Indian Life in the City," 410.

106. Colson, "A Study of Acculturation," 86; Lombard, "Migration of Women," 29.

107. Ev. A. file; S. A. M. file, Box 1, Outing Records.

108. M. B. file, Box 1, Outing Records.

109. Katherine Martin, field nurse, to Bonnie Royce, August 8, 1932 and September 5, 1932, S. B. file, Box 1, Outing Records.

110. For more on how white middle-class women's maternalism toward Indian women differed from maternalism toward other groups, see my "Great White Mother."

111. Royce to Mrs. Holcomb, field matron, Reno, July 27, 1931, E. M. file, Box 3, Outing Records.

112. Quoted in Parreñas, Servants of Globalization, 76. Many Filipina servants have had to leave their children behind in the Philippines while they work in other countries for extended periods; see Parreñas, Servants of Globalization, 62, 80, 115.

113. Notes on “outing form," March 1, 1934, March 23, [1934], and March 26, 1934, J. G. file, Box 2, Outing Records.

114. Van Every to Supt. McNeilly, November 13, 1934, A. H. file, Box 2, Outing Records.

115. R. R. Miller, Probation Officer, to Director, Indian Bureau, June 10, 1932, G. W. file, Box 4, Outing Records.

116. Royce to Snyder, July 16, 1932, G. W. file, Box 4, Outing Records.

117. Lombard, "Migration of Women," 32; Patterson, "Indian Life in the City," 410.

118. M. J. to A. D., May 15, 1929, M. J. file, Outing Records. 